[Agr. Biol. Chem., Vol. 33, No. 10, p. 1464 1469, 1969]

\title{
Change of the Gluconeogenic Capacity of Rat Kidney Cortex Slices with Dietary Components
}

\author{
By Hidetsugu Fuwa, Yukihiro Aoyama and Tomoshige Yamada \\ Laboratory of Nutritional Biochemistry, Department of Agricultural Chemistry, \\ Nagoya University, Chikusa, Nagoya \\ Received April 3, 1969
}

\begin{abstract}
Substituting protein for carbohydrate in diets significantly enhanced the rates of glucose formation from pyruvate, glutamate, or glycerol in rat kidney cortex slices. The tissue, however, increased slightly its gluconeogenic capacity in response to low carbohydrate, high fat diet. The rates of glucose taken up per unit weight of kidney cortex of rats fed a high carbohydrate diet was higher than those of rats fed diets high in protein or fat. Kidney weight in $\mathrm{g}$ per $100 \mathrm{~g}$ body weight (relative kidney size) of rats fed diets high in protein was significantly higher than that of rats fed diets high in carbohydrate or fat.
\end{abstract}

Kidney cortex slices are suitable for comparison of the rate of glucose formation under different physiological conditions, since glucose formation from a variety of noncarbohydrate precursors (gluconeogenesis) is readily measured in the tissue preparation without concomitant decomposition of glycogen and without extensive glycolysis."

Krebs et al." showed that keeping rats for 3 to 5 days on a low carbohydrate diet consisting of 3 parts of casein and 1 part of margarine plus vitamin and mineral supplements increased the gluconeogenic capacity of the tissue. They concluded that the increased gluconeogenic capacity on the low carbohydrate diet was an adaptive reaction and the body responded by synthesizing glucose when the dietary supply of glucose did not satisfy the metabolic demands of the animal.

This paper deals with measurements of the rates of renal gluconeogenesis from pyruvate, glutamate, or glycerol of rats fed low carbo-

1) H. A. Krebs, Proc. Roy. Soc., 159B, 545 (1964).

2) H. A. Krebs, D. A. H. Bennet, P. deGasquet, T. Gascoyne and T. Yoshida, Biochem. J., 86, 22 (1963). hydrate diets high in protein or fat as compared with those of rats fed a high carbohydrate diet containing adequate protein in order to test a hypothesis that the increased gluconeogenic capacity of rat kidney cortex slices depends on the content of carbohydrate in the diet. The results presented show that substituting protein for carbohydrate in diets significantly enhances the renal gluconeogenic capacity of the rat, although, rat kidney cortex increases slightly its gluconeogenic capacity in response to diets low in carbohydrate and high in fat.

\section{MATERIALS AND METHODS}

Animals and diets. Male or female Donryu strain rats were purchased from Nippon Rat Co., Urawa. The animals were housed in individual cages in a temperature regulated room at about $25^{\circ} \mathrm{C}$ and $12 \mathrm{hr}$ per day of darkness and light. Rats were fed 30 , 40 , and $45 \mathrm{kcal}$ per $100 \mathrm{~g}$ body weight per day for Expts. 1, 3, and 2, respectively, and fed ad libitum for Expt. 4. Calorie intakes per $100 \mathrm{~g}$ body weight were predetermined by separate preliminary experiments of three groups of five rats fed 25CS ad libitum under conditions comparable with Expts. 1, 2, and 3, respectively. Water was available ad libitum for 
TABLE I. Composition OF DIET (1) $25 \mathrm{CS} 40 \mathrm{CS} 55 \mathrm{CS} 65 \mathrm{CS} 75 \mathrm{CS}$

\begin{tabular}{|c|c|c|c|c|c|}
\hline & $(0.6)$ & $(0)$ & (\%) & $(0)$ & $(8)$ \\
\hline Casein & 25 & 40 & 55 & 65 & 75 \\
\hline Corn oil & 5 & 5 & 5 & 5 & 5 \\
\hline Salts mixture1) & 5 & 5 & 5 & 5 & 5 \\
\hline Vitamin mixture $e^{1,2}$ & 0.85 & 1.36 & 1.87 & $2.2 \mathrm{l}$ & 2.55 \\
\hline
\end{tabular}

1) A. E. Harper, J. Nutrition, 68, 405 (1959).

2) Thiamine $\mathrm{HCl} \quad 0.059 \%$

\begin{tabular}{ll} 
Riboflavin & 0.059 \\
Niacin & 0.294 \\
Ca pantothenate & 0.235 \\
Pyridoxine HCl & 0.029 \\
Menadione & 0.006 \\
Biotine & 0.001 \\
Folic acid & 0.002 \\
Vitamin $B_{12}$ & 0.0002 \\
Inositol & 1.176 \\
Ascorbic acid & 0.588 \\
Lactose & Made to $100 \%$ \\
\hline a
\end{tabular}

Diet also contained per $100 \mathrm{~g}: 0.15 \mathrm{~g}$ of choline chloride, $600 \mathrm{IU}$ of vitamin $\mathrm{A}, 60 \mathrm{IU}$ of vitamin $\mathrm{D}_{2}$, and $10 \mathrm{mg}$ of vitamin $\mathrm{E}$ acetate.

TABLE II. CoMposition of DIET (2)

$\begin{array}{lccccc} & 75 \mathrm{CB} & 25 \mathrm{CB} & 25 \mathrm{CL} & 25 \mathrm{C}- & 25 \mathrm{C}- \\ & (\mathrm{g}) & (\mathrm{g}) & (\mathrm{g}) & 12 \mathrm{SB} & 65 \mathrm{SB} \\ & (\mathrm{g}) & (\mathrm{g}) \\ \text { Casein } & 75 & 25 & 25 & 25 & 25 \\ \text { Butter } & 11 & 34 & 0 & 28.5 & 5.55 \\ \text { Lard } & 0 & 0 & 31.6 & 0 & 0 \\ \text { Salts mixture } & 5 & 5 & 5 & 5 & 5 \\ \text { Vitamine mixture } & 2.55 & 0.85 & 0.85 & 0.85 & 0.85 \\ \alpha \text {-Starch } & 0 & 0 & 0 & 12.3 & 64\end{array}$

1) See footnote of Table I.

2) Each diet also contained $0.15 \mathrm{~g}$ of choline chloride, $600 \mathrm{IU}$ of vitamin $A, 60 \mathrm{IU}$ of vitamin $D_{2}$, and $10 \mathrm{mg}$ of vitamin $\mathrm{E}$ acetate.

animals throughout the experiments. The composition of test diets was shown in Tables I and II. Diets were prepared by substituting (a) protein for carbohydrate at constant fat (shown in Table 1); (b) fat for carbohydrate at constant protein (shown in Table II); (c) protein for fat at constant and very low carbohydrate (shown in Table II). All the test diets contained the same amount of salts per 100 calculated calories. The amounts of the mixture of vitamins (mainly of watersoluble vitamins) used were proportional to the levels of protein in diets, namely, for example $8.5 \mathrm{~g}$ for $250 \mathrm{~g}$ of casein and $25.5 \mathrm{~g}$ for $750 \mathrm{~g}$ of casein. Commercial pellets were delivered from Central Laboratories for Experimental Animals, Tokyo and contained about 20,8 of protein.

Plan of experiments. The experiments were carried out in four phases, namely, Expts. $1 \sim 4$.

In Expt. 1, male rats maintained on a high carbohydrate diet (25\% casein-starch diet) for 3 weeks, weighing from 180 to $190 \mathrm{~g}$, were divided into three groups of six rats. Each group was fed the following diets: group 1, the high carbohydrate diet (25CS); group 2, a high protein diet $75 \%$ casein-starch diet, $75 \mathrm{CS})$; group 3 , a high fat diet $(25 \%$ casein-butter diet, 25CB). After 1 week on the test diet, glucose formation from pyruvate, glutamate, or glycerol was estimated in kidney cortex slices.

In Expt. 2, female rats maintained on the pellets, weighing from 50 to $60 \mathrm{~g}$, were divided into four groups of five rats. Each group was fed $75 \mathrm{CB}, 25 \mathrm{CB}$, $25 \mathrm{C} 12 \mathrm{BS}$, and $25 \mathrm{C} 62 \mathrm{SB}$, respectively. The former two diets were prepared by isocaloric substitution of calories from protein for those from fat at constant and very low carbohydrate. The latter three diets were prepared by isocaloric substitution of calories trom fat for those from carbohydrate at constant protein. After 2 weeks on the test diet, glucose formation from pyruvate was estimated in kidney cortex slices.

In Expt. 3, female rats maintained on 25CS for 1 week, weighing from 100 to $120 \mathrm{~g}$, were divided into four groups of five rats. Each group was fed $25 \mathrm{CS}, 40 \mathrm{CS}, 55 \mathrm{CS}$, and $65 \mathrm{CS}$, respectively, in order to test the effect of substituting protein for carbohydrate at constant fat. After 1 week on the test diet, glucose formation from pyruvate was estimated in kidney cortex slices.

In Expt. 4, female rats maintained on the pellets, weighing from 180 to $190 \mathrm{~g}$, were divided into 3 groups of five rats. Each group was fed $25 \mathrm{CS}, 75 \mathrm{CS}$, and $25 \mathrm{CL}$, respectively. After 1 week on the test diet, glucose uptake of kidney cortex slices was estimated.

Incubation of kidney cortex slices. (a) Glucose formation. The animals were killed between 10:00 a.m. and noon by a sharp blow on the head followed by decapitation. The kidneys were removed rapidly and completely, weighed, and chilled. The capsule was stripped and kidney halved. The preparation of the slices and incubation procedures were similar to 
those of Krebs et al. ${ }^{2}$, Kidney cortex slices were prepared with a Stadie-Riggs micrometer (maximum tissue thickness $0.5 \mathrm{~mm}$ ) and dropped into KrebsHenseleit buffer pH 7.4. The slices were shaken for $1 \mathrm{~min}$ at room temperatures to remove residual glucose, blotted on a filter paper, and weighed. About $50 \mathrm{mg}$ of slices $(8 \sim 12 \mathrm{mg}$ dry weight) were transferred to a $50 \mathrm{ml}$ Erlenmeyer flask containing $5.0 \mathrm{ml}$ of Krebs-Henseleit bicarbonate buffer $\mathrm{pH} 7.3 \sim 7.4$ including each of following substrates $(0.01 \mathrm{M})$ : sodium pyruvate, sodium L-glutamate, and glycerol. Flasks were stoppered with a serum stopper, gassed for $1 \mathrm{~min}$ with $95,6 \mathrm{O}_{2}-5 \% \mathrm{CO}_{2}$ via two needles, and shaken for $1 \mathrm{hr}$ about 100 oscillation per $\min$ at $37^{\circ} \mathrm{C}$. The control slices obtained from kidneys of the same rat were incubated exactly in the same manner except for the ommission of substrate. After the incubation the flasks were cooled in ice and slices were removed, dried in an oven for $2 \mathrm{hr}$ at $105 \sim 110^{\circ} \mathrm{C}$ and weighed. The medium was deproteinized with $\mathrm{HClO}_{4}$ (final concentration $0.27 \mathrm{~N}$ ) and the protein precipitates removed by centrifugation. Glucose in the supernatant was determined colorimetrically by the glucose-oxidase method of Huggett and Nixon ${ }^{3}$ as modified by Krebs et al. ${ }^{2)}$ except for the following modifications. Glucoseoxidase reagent was prepared daily from $24 \mathrm{mg}$ of glucose oxidase (Deoxin from Nagase Sangyo Co., Osaka), $100 \mathrm{ml}$ of $0.5 \mathrm{M}$ sodium phosphate buffer $\mathrm{pH}$ $7.0,0.4 \mathrm{ml}$ of $0.1 \%$ peroxidase solution (Degree of purity II from C. F. Boehringer und Soehne, GmbH, Mannheim), and $0.4 \mathrm{ml}$ of $o$-dianisidine solution $(1 \%$ in $95 \%$ ethanol). To $1.0 \mathrm{ml}$ of glucose solution $(5 \sim 25$ $\mu \mathrm{g}$ in $\left.0.27 \mathrm{~N} \mathrm{HClO}_{4}\right) 3.0 \mathrm{ml}$ of the glucose-oxidase reagent was added.
The results are reported as $\mu$ moles of extra glucose formed as a result of adding the substrate per hr per $\mathrm{g}$ dry weight of tissue.

(b) Glucose uptake. Incubation procedures were similar to those of Underwood and Newsholme, About $50 \mathrm{mg}$ of slices prepared as described above were shaken for $15 \mathrm{~min}$ at $37^{\circ} \mathrm{C}$ in Krebs-Henseleit bicarbonate buffer $\mathrm{pH} 7.4$ without substrate with $95 \% \mathrm{O}_{2}-5 \% \mathrm{CO}_{2}$ as the gas phase until glucose release of slices ceased. The slices were transferred to another flask with medium containing $2 \mathrm{mM}$ D-glucose with 95\% $\mathrm{O}_{2-5} \mathrm{CO}_{2}$ as the gas phase and incubated for $2 \mathrm{hr}$ at $37^{\circ} \mathrm{C}$ with shaking. After the incubation the weight of slices and glucose in the medium were determined as described in $(a)$.

The results are reported as $\mu$ moles of glucose taken up per hr per g dry weight of tissue.

\section{RESULTS}

Table III shows the results of Expt. 1. There was a significant increase of $41 \%, 33 \%$, and $41 \%$ in the rates of renal gluconeogenesis per unit weight with pyruvate, glutamate, and glycerol, respectively, as substrate in rats fed the high protein, low carbohydrate diet as compared with rats fed the high carbohydrate diet. Because the weight of kidneys increased in response to the high protein diet on average about $30 \%$, the effect of the diet expressed as the rates of gluconeogenesis per kidney per $100 \mathrm{~g}$ body weight might be highly

\section{Table III. Changes of the Rates of Glucose formation from Pyruvate, Glutamate, or Glycerol in Kidney Cortex Slices and Relative Kidney Size of Rats Fed High Carbohydrate, High Protein, or High fat Diets}

\begin{tabular}{lccrc} 
& $25 \%$ Casein-starch diet & $75 \%$ Casein-starch diet & $25 \%$ Casein-butter diet \\
Pyruvate & $135 \pm 24.2^{11}(5)$ & $191 \pm 22.3^{*}(6)$ & $149 \pm 15.6 \quad(6)$ \\
Glutamate & $62.7 \pm 11.7(5)$ & $89.6 \pm 20.3^{* *}(6)$ & $63.8 \pm 6.2(6)$ \\
Glycerol & $58.3 \pm 10.9(5)$ & $82.4 \pm 5.9^{*}(4)$ & $74.0 \pm 6.9^{* *}(5)$ \\
& \multicolumn{5}{c}{ Kidney weight in $\mathrm{g} / 100 \mathrm{~g}$ body weight } \\
& $0.822 \pm 0.042(6)$ & $1.08 \pm 0.052^{*}(6)$ & $0.818 \pm 0.041(6)$
\end{tabular}

1) Mean \pm standard deviation for number of rats indicated in parentheses.

*.** Differs significantly from corresponding values in animals fed $25 \mathrm{CS}$ at the $1 \%$ and $5 \%$ levels, respectively, by $t$ test.

3) A. St G. Huggett and D. A. Nixon, Biochem. $J, 66,12 \mathrm{P}(1957)$.
4) A. H. Underwood and E. A. Newsholme, Biochem. J., 104, 300 (1967). 


\section{Table IV. Effect of Substituting Protein or Fat for Dietary Carbohydrate on the Rate of Glucose formation from Pyruvate in Kidney Cortex Slices AND RELATIVE KIDNEY SIZE OF RATS}

$25 \%$ Casein-62\% starch butter $25 \%$ Casein-12\% starch butter $25 \%$ Casein-butter $75 \%$ Casein-butter

$$
\begin{array}{cccc} 
& \mu \text { moles of extra glucose formed from pyruvate/g dry weight/hr } \\
227 \pm 11.7^{13} & 253 \pm 18.3 & 285 \pm 25.7 & 303 \pm 21.5^{*} \\
& \text { Kidney weight in } \mathrm{g} / 100 \mathrm{~g} \text { body weight } & \\
0.984 \pm 0.064 & 0.961 \pm 0.084 & 0.988 \pm 0.145 & 1.33 \pm 0.065^{*}
\end{array}
$$

1) Mean \pm standard deviation for five rats.

* Differs significantly from corresponding values of animals fed $25 \mathrm{C} 62 \mathrm{SB}$ at the level of $0.1 \%$, by $t$ test.

Table V. EfFect of Substituting Protein for Deitary Carbohydrate on the Rate of Glucose Formation from pyruvate in Kidney CORTEX Slices and Relative KidNeY Size of Rats

$$
\begin{array}{cccc}
25 \% \text { Casein-starch } & 40 \% \text { Casein-starch } & 55 \% \text { Casein-starch } & 65 \% \text { Casein-starch } \\
\mu \text { moles of extra glucose formed from pyruvate/g dry weight/hr } & \\
178 \pm 29.6^{1 /}(5) & 190 \pm 17.0(5) & 232 \pm 27.2(5) & 249 \pm 23.9 *(4) \\
& \text { Kidney weight in } \mathrm{g} / 100 \mathrm{~g} \text { body weight } & \\
0.884 \pm 0.033(5) & 0.996 \pm 0.072^{*}(5) & 1.04 \pm 0.096 *(5) & 1.18 \pm 0.173^{*}(4)
\end{array}
$$

1) Mean \pm standard deviation for number of rats indicated in parentheses.

* Differs significantly from corresponding values in animals fed $25 \mathrm{CS}$ at the level of $5 \%$, by $t$ test.

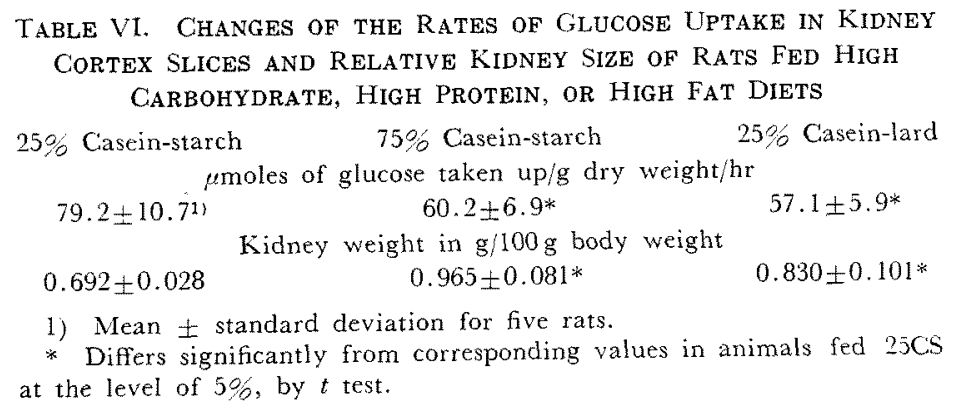

significant. Tissues from rats fed the high fat, low carbohydrate diet showed about the same gluconeogenic capacity as that of rats fed the high carbohydrate diet except for glycerol as substrate. The animals showed almost the same gain in body weight per day among each group from the 3rd to 7 th day of the experimental duration, although rats fed the high protein diet lost or maintained their body weight for one or two days at the beginning of the experiment.

Results of Expts. 2 and 3 are shown in
Tables IV and V. The capacity of glucose formation from pyruvate in rat kidney cortex slices increased when more carbohydrate in diet was replaced with protein at constant fat content. Substituting fat for carbohydrate in diet at constant protein content, however, showed slight and insignificant increase of the gluconeogenic capacity of the tissue.

Table VI shows the results of Expt. 4. The rates of glucose taken up per unit weight of kidney cortex of rats fed the high carbohydrate diet was significantly higher than those 
of rats fed diets high in protein or fat. However, owing to the increased weight of the kidneys in response to the high protein diet, the rates per kidney per $100 \mathrm{~g}$ body weight might be similar between the high carbohydrate and the high protein groups.

\section{DISCUSSION}

The experimental data described in Tables III, IV and $\mathrm{V}$ indicate the capacity of glucose formation in rat kidney cortex slices increases when the content of protein in diets increases. Although an increased capacity of glucose formation in the tissue of rats fed a low carbohydrate diet has been observed by Krebs et al. ${ }^{2 \prime}$ the increased capacity depends on the high protein content of diets and not on the low carbohydrate content.

The data described in Table VI indicate the capacity of glucose uptake of kidney cortex slices of rats fed the high carbohydrate diet is higher than those of rats fed diets high in protein or fat. This is not enough to account for the increased capacity of glucose formation in the tissue of rats fed the high protein diet, however, especially when the capacity is expressed as the rate per kidney per $100 \mathrm{~g}$ body weight, since relative kidney size of rats increases in response to the high protein diet.

Thus, it is possible to conclude that administration of diets high in protein to rats produces a marked increase in renal glucose synthesis from noncarbohydrate precursors. The regulation of gluconeogenesis in liver and kidney by means of dietary components has received little attention. It has been suggested that two types of mechanisms can be distinguished in case of control of lipogenesis. ${ }^{5}$ Namely, one is short term and the other is long term. The long term effects have been found to correlate with "adaptive" changes

5) J. M. Lowenstein in "The Metabolic Roles of Citrate", ed. by T. W. Goodwin, Academic Press Inc., New York, N.Y., 1968, p. 82. in the activity of the enzymes involved in the system. The reversibility of glycolysis has been considered by Krebs ${ }^{6 /}$ and Weber" to depend on the activity of glucose 6-phosphatase, fructose 1,6-diphosphatase, phosphoenolpyruvate carboxykinase, and pyruvate carboxylase. In addition, transamination and deamination of glucogenic amino acids has been considered. It is possible that an increase in renal gluconeogenesis of rats fed diets high in protein may be due to an increase in the activity of these enzymes in the kidney. ${ }^{8}$

It has been shown that the rates of incorporation of radioactivity in blood glucose and liver glycogen from ${ }^{14} \mathrm{C}$-pyruvate or ${ }^{14} \mathrm{C}$-amino acids increased more in rats fed diets high in protein $^{9,10}$ or fat ${ }^{101}$ than in rats fed diets high in carbohydrate. The increased incorporation of ${ }^{14} \mathrm{C}$ can be in consequence of either increased glucose synthesis, or decreased utilization of glucose, or both. It is probable, however, that the capacity of glucose formation increased in rats fed diets low in carbohydrate and high in protein or fat.

Liver and kidney cortex are unique in higher animals in that they are capable of both degradation and synthesis of glucose. The quantitative roles of the liver and kidneys in gluconeogenesis has been discussed by Krebs." Although Krebs et al. ${ }^{111}$ have shown that a low carbohydrate diet high in fat did not increase the gluconeogenic capacity of mouse liver slices, we have observed an increased capacity of glucose formation in rat liver slices ${ }^{12 !}$ and homogenates ${ }^{8 !}$ when rats

6) H. A. Krebs, Johns Hopkins Hosp. Bull., 95, 19 (1954).

7) G. Weber, Advances in Enzyme Regulation, 1, 1 (1963).

8) H. Fuwa, H. Suzuki and J. Nagata, Agr. Biol. Chem., 33, 1470 (1969).

9) T. Kimura and K. Ashida, Agr. Biol. Chem., 32, 1440 (1968); Unpublished observation.

10) B. Friedman, E. H. Goodman, Jr. and S. Weinhouse, J. Biol. Chem., 242, 3620 (1967).

11) H. A. Krebs, B. M. Notton and R. Hims, Biochem. J., 101, 607 (1966).

12) H. Suzuki and H. Fuwa, Unpublished observation. 
vere fed with diets high in protein or fat. of free fatty acids on gluconeogenesis in This may account for the increased capacity liver ${ }^{132}$ and kidney cortex. ${ }^{141}$ The control of in vivo glucose formation of rats fed diets mechanisms of gluconeogenesis in liver and ligh in fat and low in carbohydrate. An kidney by means of dietary components are Iternative explanation is stimulatory effects under investigation.

13) R. J. Haynes, Advances in Enzyme Regulation, 3, 118 (1965); E. Struck, J. Ashmore and O. Wieland, Biochem. Z., 343, 107 (1965); J. R. Williamson, Ad
yances in Enzyme Regulation, 5, 229 (1967).

14) H. A. Krebs, R. N. Speake and R. Hems, Biochem. J., 94, 712 (1965); A. H. Underwood and E. A. Newsholme, Biochem. J., 104, 300 (1967); H. Fuwa and Y. Asano, Unpublished observation. 